\title{
Sistem Informasi Pelayanan Medis Pasien di Klinik Insani Citeureup Berbasis Java
}

\author{
Rina Deviana Alit ${ }^{1}$, Meri Chrismes Aruan ${ }^{2}$, Andri Rahadyan ${ }^{3}$ \\ ${ }^{1,2,3}$ Program Studi Teknik Informatika Universitas Indraprasta PGRI, Jl Raya Tengah No.80, Rt 06/Rw 01, Gedong, Kec. Ps.Rebo,Jaktim 13760 \\ ${ }^{1}$ rinadevana22@gmail.com, ${ }^{2}$ meriprincess08aruan@gmail.com, ${ }^{3}$ andri.rahadyan@ gmail.com
}

\section{INFORMASI ARTIKEL}

\section{Sejarah Artikel:}

Diterima Redaksi: 27 Januari 2020

Revisi Akhir: 19 April 2020

Diterbitkan Online: 24 April 2020

\section{KATA KUNCI}

Perancangan,

Sistem Informasi,

Pelayanan Medis,

Pengolahan Data Berobat,

Administrasi Pasien

KORESPONDENSI

Telepon: 083819399835

E-mail: rinadeviana22@gmail.com

\section{A B $\mathbf{S}$ T $\mathbf{R}$ A $\mathbf{C}$ T}

The purpose of this research is to design a medical service information system for Java-based human citeureup clinical patients to accelerate and manage patient data, search for medical service information systems and to produce medical service information systems in Java-based human clinical clinics. The research method used by researchers is a qualitative research method that is research on research conducted descriptive and using analysis. The results obtained were about medical service information systems to assist in processing patient data. The construction of this information system is expected to facilitate and provide maximum service to patients as well as facilitate the processing of transaction data for reporting, data and information management processes become efficient because data processing has been computerized, produce faster output in less than 5 minutes and minimize errors data input or duplication of data.in less than $95 \%$.

\section{PENDAHULUAN}

Pelayanan medis merupakan suatu cara yang dipakai dalam memberikan pelayanan kesehatan kepada masyarakat. Serta dapat diartikan sebagai cara yang dilakukan untuk memberikan pelayanan kepada masyarakat yang sedang sakit dan membutuhkan perawatan medis.

Pelayanan medis di Klinik Insani merupakan salah satu usaha yang bergerak di bidang kesehatan dengan kunjungan pasien berobat yang relatif banyak. Dengan demikian, untuk mengelola data pasien yang berobat, pihak klinik membutuhkan tempat yang banyak untuk menyimpan arsip-arsip selama bertahun-tahun karena belum adanya sistem yang dapat menyimpan data dalam sebuah database secara terstruktur. Dalam pengarsipan data pasien dan pelayanan medis di Klinik Insani Citeureup terdapat beberapa permasalahan diantaranya karena masih menggunakan media kertas dalam melakukan pengolahan data pasien. Kondisi penyimpanan data sering mengakibatkan pencarian data saat dibutuhkan menjadi lambat sehingga dapat mengganggu kelancaran proses pelayanan medis pada klinik. Penyimpanan yang tidak terstruktur juga mengakibatkan penumpukan data kerusakan bahkan kehilangan data.

Dengan timbulnya permasalahan dalam mengolah data pasien yang akan berobat tersebut maka diperlukannya membangun sebuah perancangan aplikasi pelayanan medis yang bisa mengolah data secara efisien. Diharapkan mampu meningkatkan kualitas pelayanan petugas terhadap pasien serta sistem informasi yang dihasilkan dapat sesuai dengan harapan dan dapat mempermudah dalam mendapatkan informasi yang dibutuhkan serta dapat dengan mudah melayani pasien yang datang untuk berobat. Dengan adanya sistem yang terkomputerisasi diharapkan dapat meningkatkan keefisienan dalam pengolahan data dan kualitas pelayanan serta dapat meminimalisasi kesalahan dan meningatkan keamanan data pasien.

Dibuatnya aplikasi perancangan sistem informasi pada pasien di Klinik Insani Citeureup berbasis java yaitu untuk mempercepat dan mempermudah kinerja dalam pengolahan, pencarian dan penyimpanan data pasien, serta menghasilkan sebuah sistem informasi pelayanan medis pada pasien klinik insani citeureup berbasis java. 
Penelitian ini dilaksanakan di Klinik Insani Citeureup yang membutuhkan sistem aplikasi pelayanan medis yang terkomputerisasi dengan maksud memberikan kemudahan bagi klinik dalam pengolahan data pasien serta sebagai bahan pertimbangan dan masukan bagi Klinik Insani mengenai sistem aplikasi pengolahan data pasien yang dapat membantu dalam penyelesaian masalah pelayanan medis. Teknik pengumpulan data yang digunakan dalam pembuatan aplikasi ini adalah; Wawancara, Observasi dan Dokumentasi.

\section{TINJAUAN PUSTAKA}

\subsection{Perancangan}

Perancangan adalah proses penggambaran, perencanaan pembuatan sketsa atau pengaturan dari beberapa elemen yang tepisah dari suatu kesatuan yang utuh dan berfungsi [1]. Berdasarkan definisi diatas dapat disimpulkan bahwa perancangan merupakan cara untuk memecahkan masalah selama tahap analisis dalam suatu instansi.

Tahap perancangan adalah tahap merancang sistem secara terperinci berdasarkan hasil analisis sistem yang didapat sehingga menghasilkan suatu sistem baru yang diharapkan dapat menyelesaikan masalah yang timbul pada suatu instansi. Tahap perancangan menurut beberapa ahli, antara lain: perancangan ouput, perancangan input, perancangan proses sistem. Perancangan database dan tahapan perancangan kontrol.

\subsection{Sistem}

Sistem adalah suatu jaringan kerja dari prosedurprosedur yang saling berhubungan, berkumpul bersamasama untuk melakukan suatu kegiatan atauuntuk menyelesaikan suatu sasaran tertentu [2]. Sebuah sistem memiliki karakteristik diantaranya:

1. Mempunyai komponen

2. Batasan Sistem

3. Lingkungan luar sistem

4. Penghubung sistem

5. Masukan sistem (input)

6. Keluaran sistem (output)

7. Pengolahan sistem (process)

8. Sasaran sistem (objective)

Sistem dapat diklasifikasikan menurut beberapa sudut pandang, antara lain:

1) Sistem Abstrak dan Sistem Fisik

2) Sistem Alamiah dan Sistem Buatan Manusia

3) Sistem Deterministik dan Sistem Probabilistik

4) Sistem Terbuka dan Tertutup

Sistem informasi merupakan gabungan yang terdiri dari manusia, teknologi informasi dan prosedur kerja yang memproses, menyimpan, menganalisis dan menyebarkan informasi untuk mencapai suatu tujuan [3]. Informasi sendiri merupakan sekumpulan data yang telah diolah sehingga mempunai nilai dan makna bagi yang menerimanya. Tiga hal pokok dalam menentukan kualitas suatu informasi, yaitu :
1. Akurat
2. Tepat waktu
3. Relevan

\subsection{Konsep Dasar Java}

Java adalah bahasa pemrograman network friendly (yang bisa mudah berpadu dengan suatu jaringan) yang dibangun oleh Sun Microsystem yang digunakan untuk membangun sistem yang besar dan kompleks yang melibatkan beberapa komputer berbeda [4]. Kelebihan dari java adalah multiplatform. Class library yang lengkap, yaitu memudahkan penggunaan oleh para programmer untuk membangun aplikasinya [5]. Dan yang terakhir yaitu bergaya $\mathrm{C}++$ merupakan sintaks yang dapat digunakan untuk proses bahan ajar atau ingin meningkatkan keahlian dibidang computer.

\section{a. Netbeans}

Netbeans adalah sebuah (IDE) Integrated Development Environment Open Source yang sering diasosiasikan dengan java. NetBeans merupakan sebuah aplikasi (IDE) Integrated Development Environment yang berbasis Java dan Sun Microsystem yang berjalan di atas swing dan banyak digunakan sekarang sebagai editor untuk berbagai bahasa pemrograman [6]. Suatu IDE (Integrated Development Environment) adalah lingkup pemrograman yang di integrasikan ke dalam suatu aplikasi perangkat lunak yang menyediakan pembangunan Graphic User Interface (GUI) suatu text atau kode editor, suatu compiler atau interpreter, dan suatu debugger [7]. Netbeans merupakan software development open source. Dengan kata lain software ini di bawah pengembangan bersama dan bebas biaya.

\section{b. XAMPP}

$X A M P P$ adalah software bebas yang mendukung banyak sistem operasi. XAMPP merupakan kompilasi dari beberapa program [8].

\subsection{Konsep Dasar Database}

Database ialah sekumpulan data yang disimpan dalam komputer secara sistematik sehingga dapat diperiksa dengan suatu program komputer untuk memperoleh informasi dari database tersebut. "database adalah tempat media penyimpanan data dalam membuat sebuah program yang berisikan tabel dan record' [9].

\section{a. $M y S Q L$}

MySQL ialah software sistem manajemen DBMS yang multiuser. Karena sifatnya yang open source dan memiliki kemampuan menampung kapasitas yang sangat besar, maka MySQL menjadi database yang sangat populer di kalangan programer web.

MySQL merupakan sebuah program database server yang mampu menerima dan mengirimkan datanya dengan sangat cepat, multiuser serta menggunakan perintah standar SQL (Structured Query Languange) [10] .

MySQL memiliki banyak sekali keistimewaan. Berikut ini beberapa keistimewaan MySQL.
1. Probability
2. Open Source
3. Multiuser
4. Performance Turning
5. Columnar Types
6. Command and Functions
7. Security
8. Scability dan komite 


\section{Connection \\ 10. Localitation \\ 11. Interface}

\section{METODOLOGI}

Metode yang digunakan peneliti yaitu menggunakan metode kualitatif. Yaitu penelitian yang menggunakan analisis. Metode pengumpulan data dilakukan selama 2 bulan dengan menggunakan dua cara yaitu Data primer dilakukan dengan melakukan sesi tanya jawab antara dua orang untuk memperoleh informasi dengan mengajukan beberapa pertanyaan berdasarkan tujuan penelitian. Selain itu dengan cara observasi langsung di Klinik Insani Citeureup. Pengumpulan data sekunder yaitu mempelajari berbagai sumber data dari Klinik Insani seperti data pelayanan medis, sejarah klinik insani, struktur organisasi, visi dan misi klinik insani, data pendaftaran pasien, data pasien atau data dokter dan transaksi pada klinik insani citeureup.

\section{HASIL DAN ANALISIS}

Sumber pustaka/rujukan sedapat mungkin merupakan pustaka-pustaka terbitan 10 tahun terakhir. Pustaka yang diutamakan adalah naskah-naskah penelitian dalam jurnal, konferensi dan/atau majalah ilmiah.Pustaka lain dapat berupa buku teks atau laporan penelitian (termasuk Skripsi/Tugas Akhir, Tesis, dan Disertasi), akan tetapi diusahakan tidak melebihi $20 \%$ dari seluruh jumlah sumber pustaka.

Pada bagian sistem pendaftaran pasien di mana sistemnya belum menggunakan komputer atau masih manual sehingga ada laporan atau catatan yang ditulis tangan, sehingga apabila ada kesalahan-kesalahan pengolahan data penyebab dari kesalahan tersebut juga dikarenakan terlalu banyak dokumen yang harus dibuat yang menyebabkan prosedur sistem berjalan terlalu rumit. Pada laporan tahunan, petugas klinik harus mengumpulkan data-data yang cukup banyak, sehingga petugas klinik membutuhkan waktu yang sangat lama dalam pembuatannya. Berdasarkan analisis sistem yang sedang berjalan saat ini penyusun melihat adanya kekurangan, maka dari dibuat aturan yang akan memberikan beberapa saran sebagai alternatif penyelesaian masalah. Aturan tersebut meliputi pendaftaran pasien terlebih dahulu di bagian pendaftaran dengan menyerahkan fotocopy KTP untuk dicatat identitasnya oleh petugas pendaftaran. Selanjutnya yaitu rekam medis, dimana setelah pasien diperiksa, dokter akan mencatat penyakit atau diagnosa pasien pada data rekam medis. Kemudian dokter akan membuatkan resep untuk pasien. Aturan selanjutnya pasien membawa resep tersebut ke bagian depo obat dan akan dihitung biaya pemeriksaan, biaya obat dan biaya lainnya. Kemudian pasien akan dibuatkan kuitansi sebagai tanda bukti pembayaran. Setelah itu laporan dibuat untuk mengetahui data pasien yang berkunjung setiap harinya dan diserahkan kepada pimpinan klinik. Berikut gambar dekomposisi fungsi sistem.

\subsection{Diagram Alir Data (DAD) Sistem yang Berjalan}

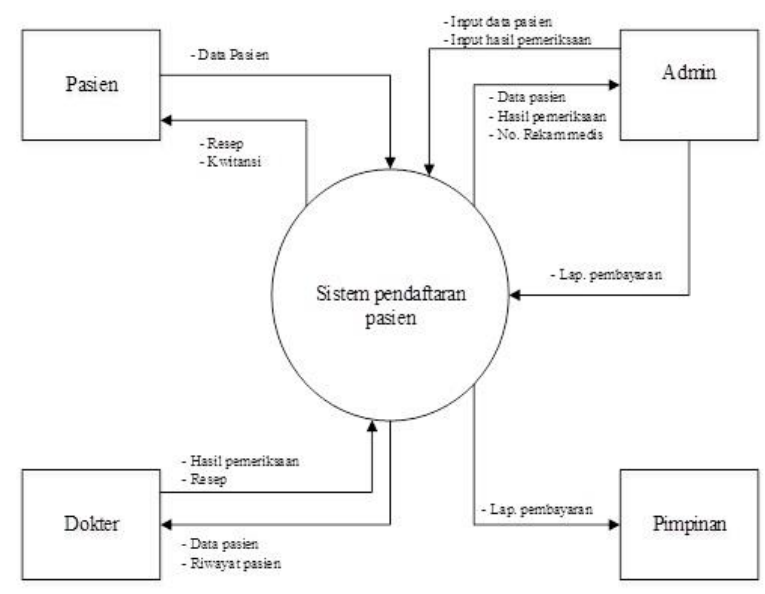

Gambar 1. Diagram Konteks Sistem Berjalan

Dari hasil penelitian penulis dapat mengambil kesimpulan bahwa

a. Data masukan terhadap data pendaftaran dari pasien yang diterima oleh admin sistemnya belum menggunakan computer sehingga ada laporan atau catatan yang ditulis tangan

b. Kesalahan-kesalahan pengelola data dikarenakan terlalu banyak dokume yang harus dibuat yang menyebabkan prosedur sistem berjalan terlalu rumit

c. Pada laporan tahunan, petugas harus mengumpulkan data-data yang cukup banyak, sehingga petugas membutuhkan waktu yang sangat lama dalam pembuatannya

\section{Alternatif Penyelesaian Masalah}

Untuk penyelesaian masalah diatas maka diusulkan beberapa alternative

a. Membangun sistem informasi yang sudah terkomputerisasi yang dapat membantu kinerja pegawai dalam pengolahan data pasien.

b. Perancangan database sistem untuk penyimpanan data agar lebih efisien dan lebih akurat serta dapat mengurangi adanya kemungkinan kehilangan data.

c. Pada pembuatan laporan pasien dapat tertata rapih melalui sebuah sistem informasi.

\subsection{Diagram Alir Data (DAD) yang Diusulkan}

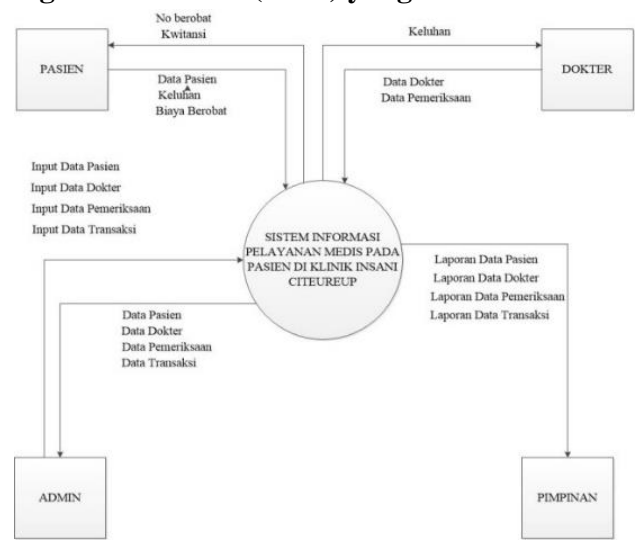

Gambar 2. Diagram Konteks Sistem Diusulkan 


\subsection{Entity Relationship Diagram (ERD)}

Entity Relationship Diagram (ERD) merupakan sebuah cara mudah untuk menggambarkan struktur logis dari sebuah basis data dalam sebuah cara piktoral.

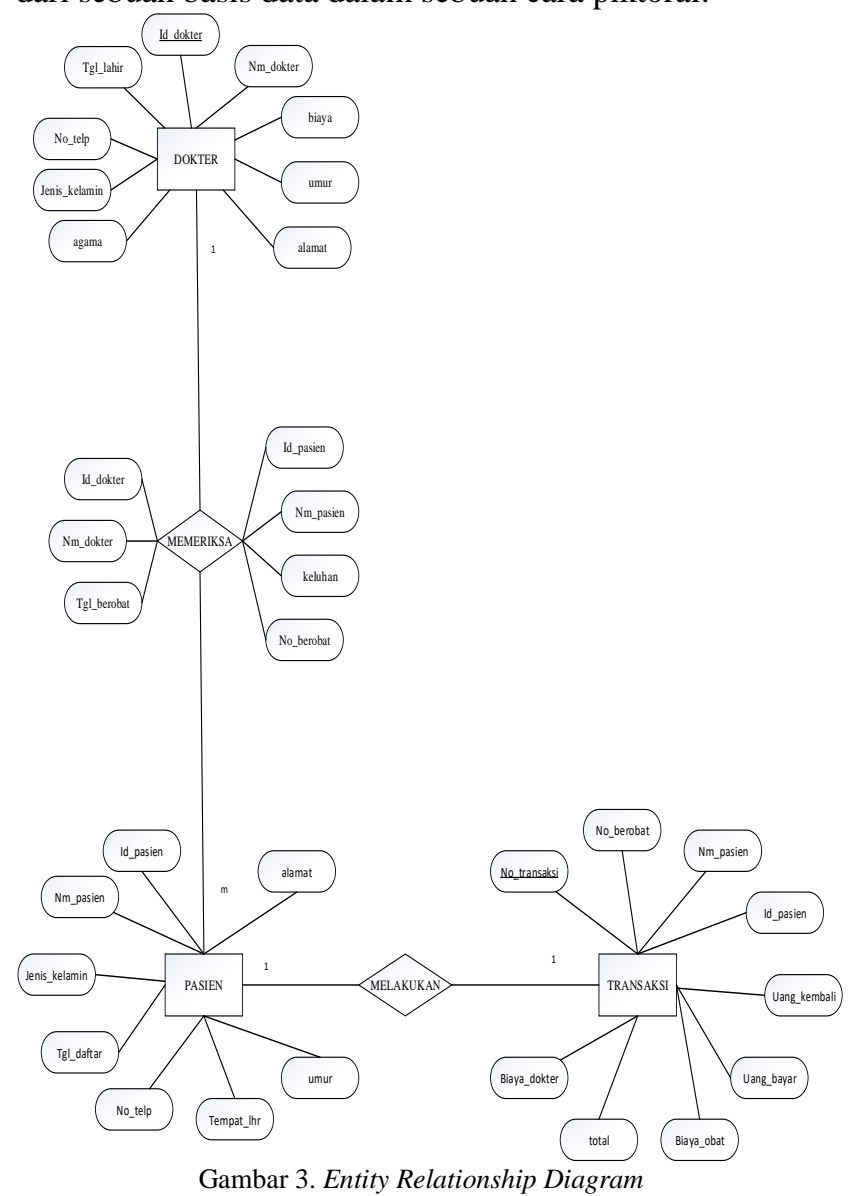

\subsection{Desain Antarmuka Aplikasi}

Berikut adalah perancangan desain antarmuka aplikasi yang akan dibuat, segala desain adalah bentuk landscape dikarenakan ini adalah desain antar muka aplikasi komputer, yang pastinya sistem ini akan memenuhi kebutuhan dan syarat-syarat yang perlu untuk memastikan informasi yang penting dapat disampaikan kepada pengguna aplikasi.

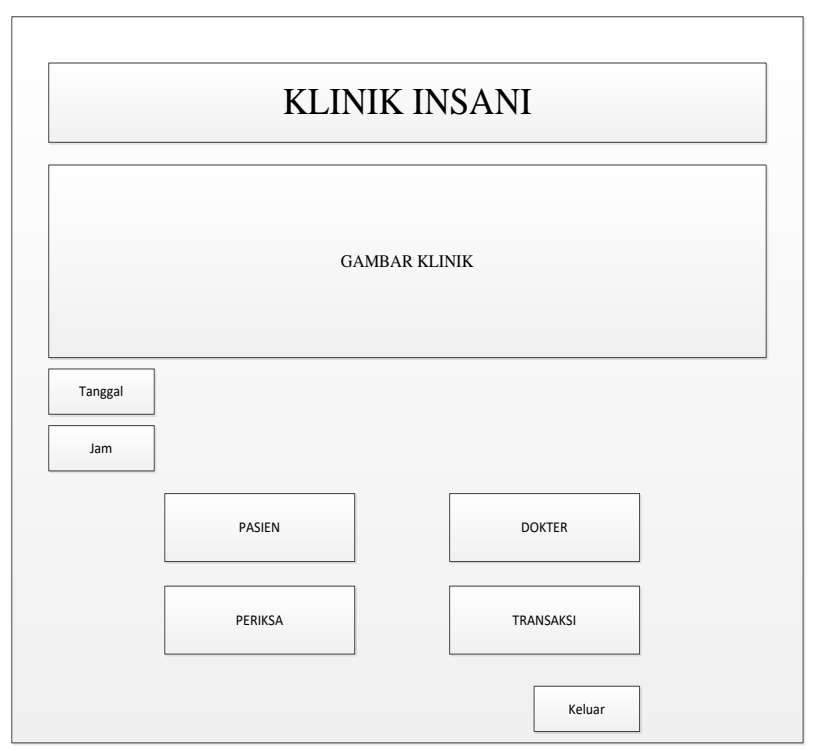

Gambar 4. Desain Antarmuka Aplikasi

\subsection{Perancangan Sistem}

Halaman pertama yang akan dilihat pengguna aplikasi pada saat instalasi pertama, pengguna aplikasi dapat melakukan otentikasi dengan memasukkan username dan passaword yang diisi oleh admin klinik.

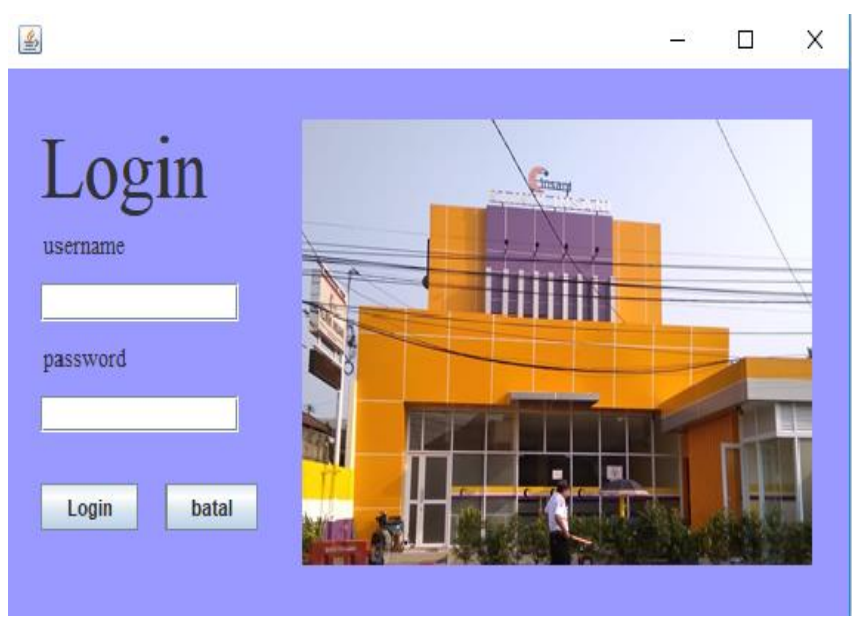

Gambar 5. Tampilan Awal

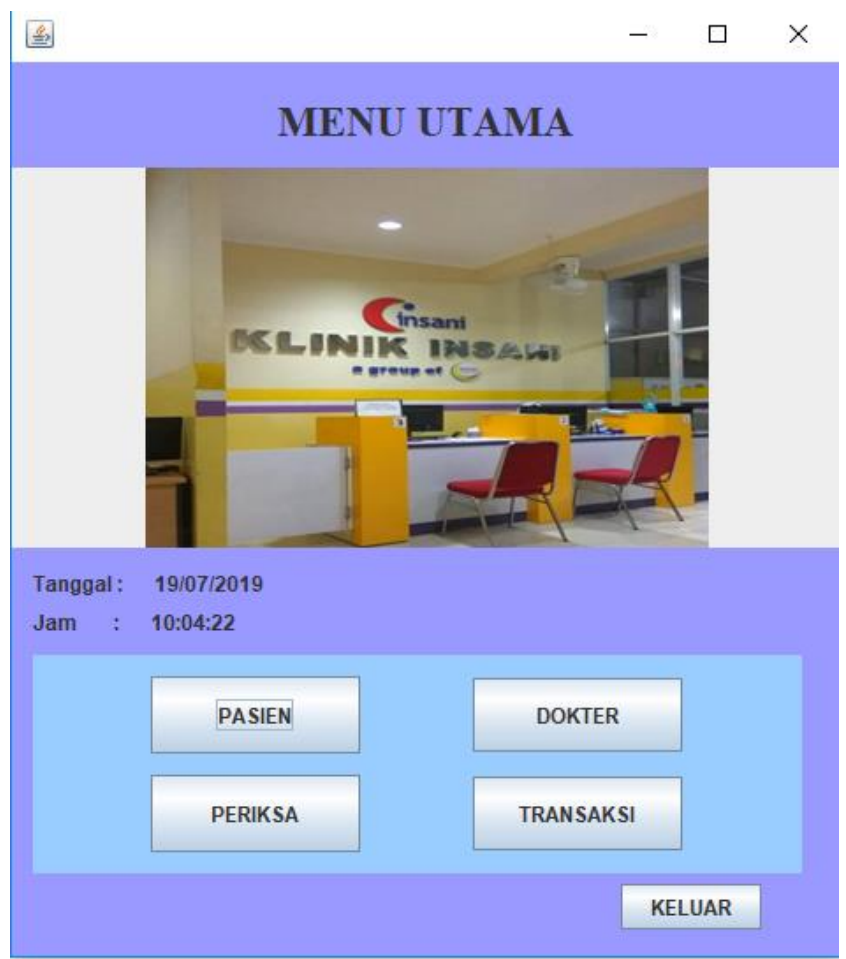

Gambar 6. Tampilan Halaman Utama

Gambar 6 merupakan halaman utama aplikasi, pada halaman ini pegguna aplikasi dapat langsung melihat informasi yang dibutuhkan pada saat mendaftar. 


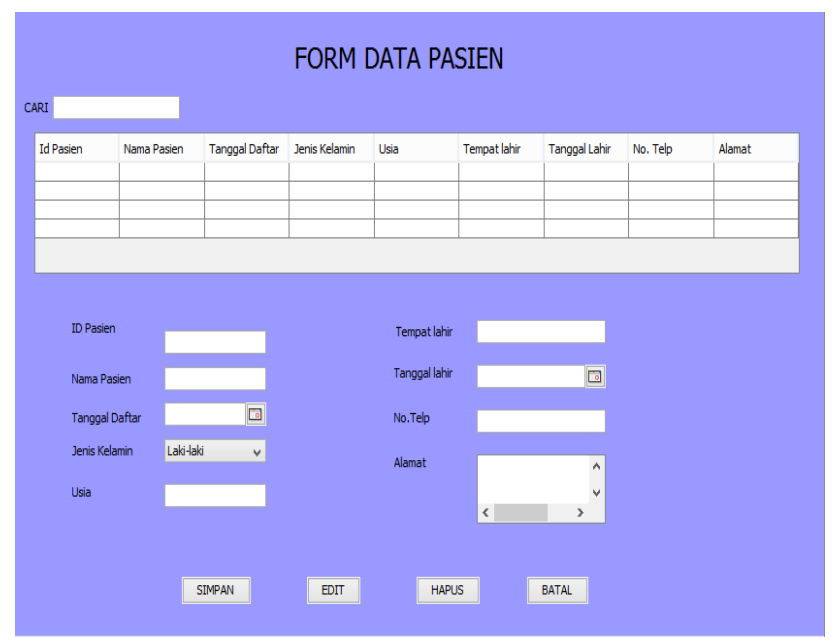

Gambar 7. Tampilan Sistem Data Pasien

Pada Gambar 7 berisikan biodata pasien yang mendaftar untuk menginput dan menyimpan semua data pasien yang akan berobat di Klinik Insani Citeureup.

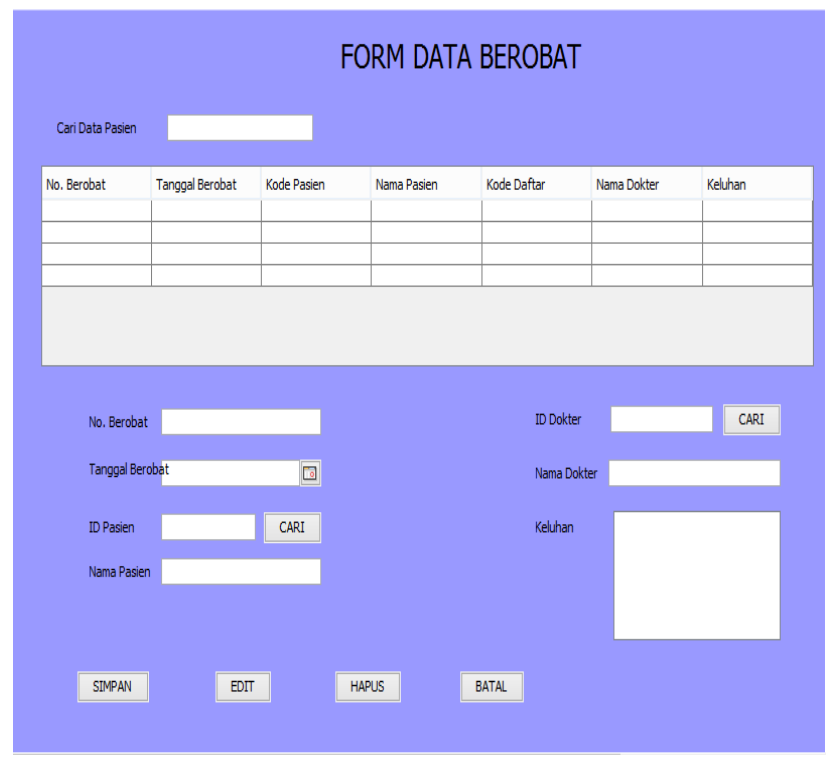

Gambar 8. Tampilan Sistem Data Dokter

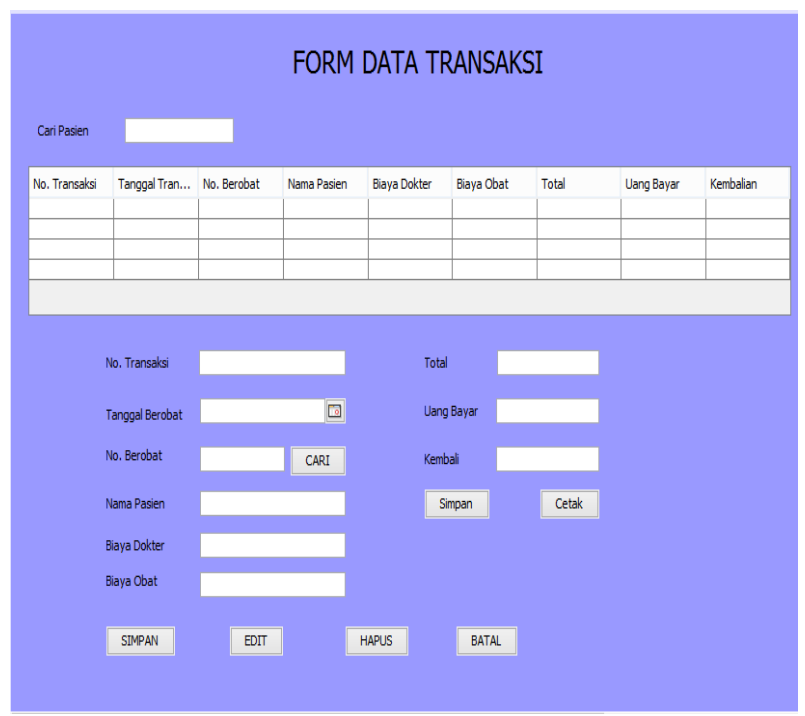

Gambar 9. Tampilan Sistem Data Transaksi
Kemudian pada Gambar 9 Form Transaksi untu menyelesaikan proses transaksi pasien setelah dilakukan pemeriksaan dan setelah menerima obat.

\subsection{Tampilan Laporan Sistem}

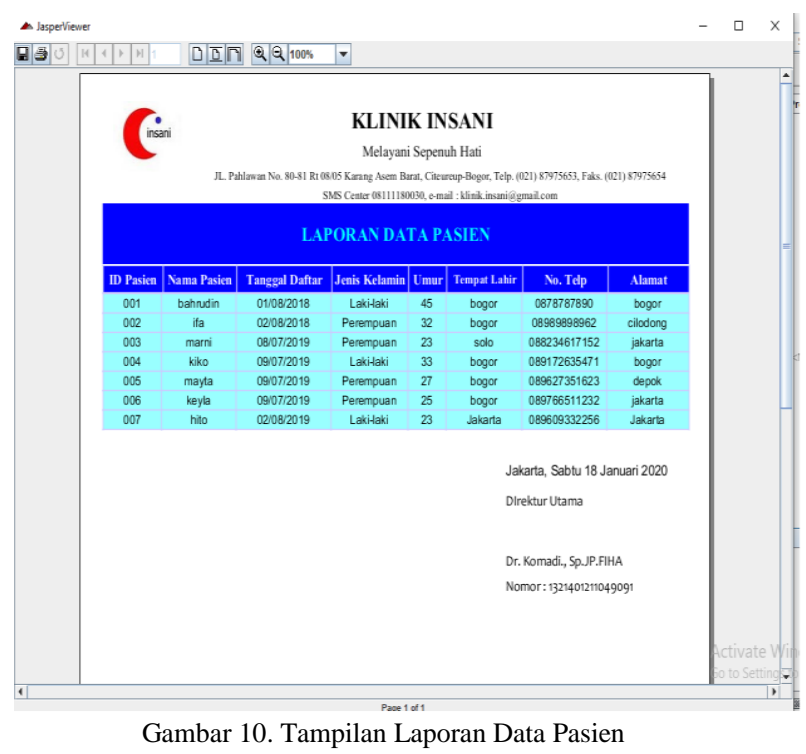

Pada Gambar 10 merupakan tampilan laporan data pasien yang nantinya diserahkan dan ditandatangani oleh Direktur Utama Klinik Insani Citeureup.

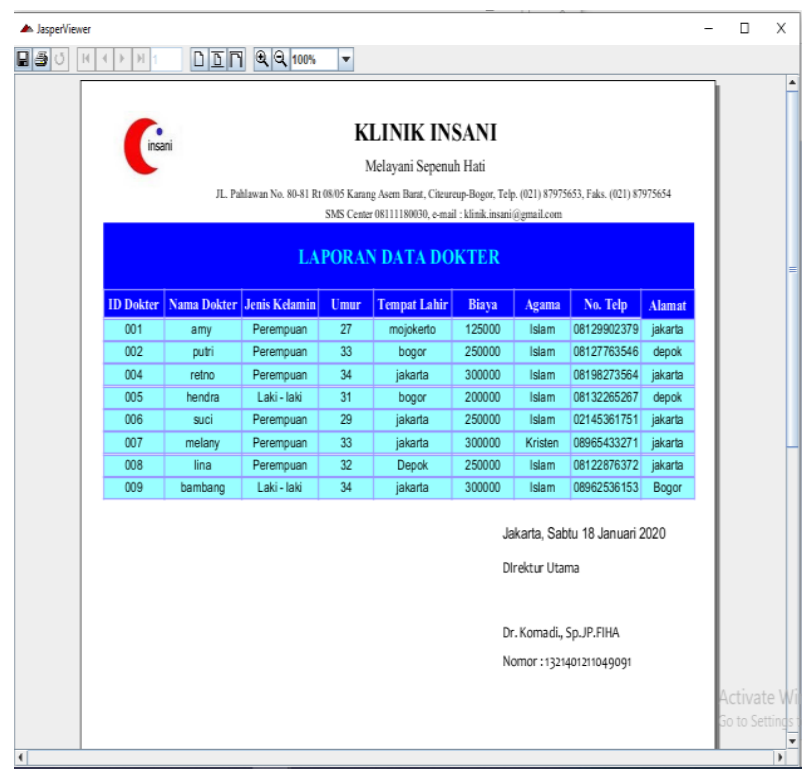

Gambar 11. Tampilan Laporan Data Dokter

Kemudian pada Gmabar 11 Tampilan Laporan Data Dokter yang berisikan informasi dan pembiayaan terhadap dokter yang bertugas di Klinik Insani Citeureup. 


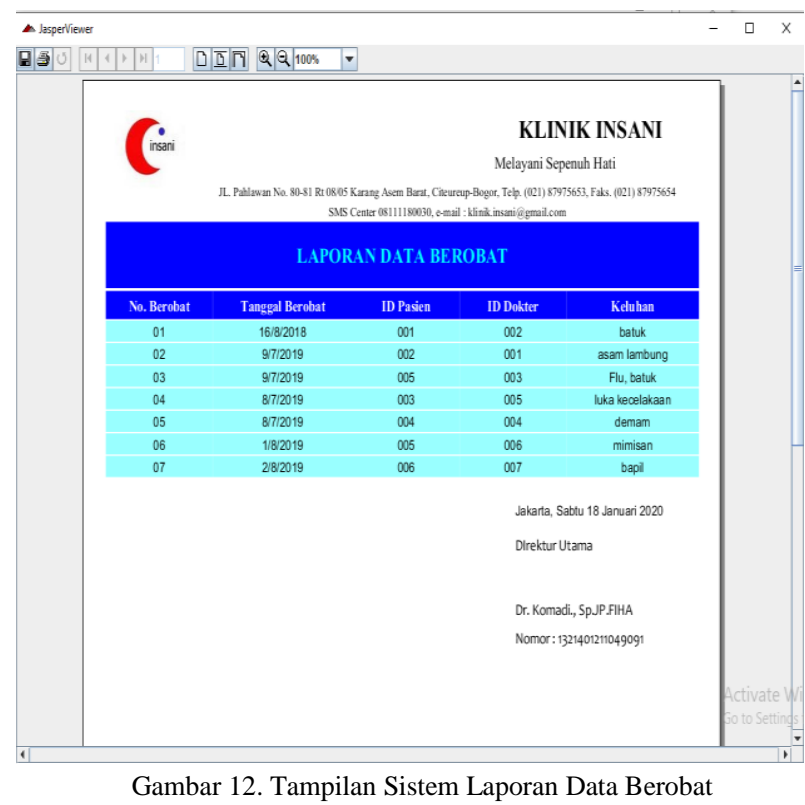

Pada Gambar 12 Tampilan Laporan Data Berobat seluruh pasien di Klinik Insani yang nantinya diserahkan dan dtandatangani oleh Direktur Utama Klinik Insani dan disimpan sebagai arsip klinik.

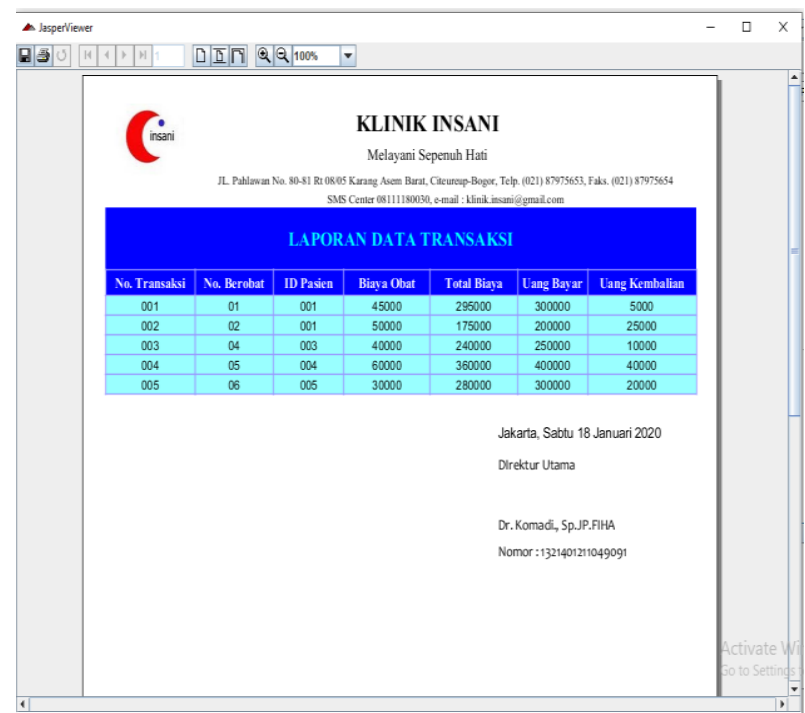

Gambar 13. Tampilan Laporan Data Transaksi

Selanjutnya pada Gambar 13 merupakan tampilan laporan data transaksi kunjungan pasien yang nantinya di serahkan dan ditandatangani oleh Direktur Utama Klinik Insani kemudian disimpan sebagai arsip klinik.

\section{KESIMPULAN}

Berdasarkan hasil pengujian terhadap aplikasi sistem yang dibangun, kesimpulannya adalah:

1. Merancang sistem informasi pelayanan medis pada pasien di Klinik Insani Citeureup berbasis Java untuk membantu petugas dalam melakukan pengolahan data pasien serta mempermudah petugas dalam proses pengumpulan data transaksi untuk pembuatan laporan
2. Dengan adanya pengolahan data yang terkomputerisasi, proses manajemen pengolahan data dan informasi menjadi lebih efisien, menghasilkan output yang lebih cepat sehinggan masalah-masalah yang terjadi pada Klinik Insani dapat terselesaikan.

\section{DAFTAR PUSTAKA}

[1] Jogiyanto, "Analisis dan Desain," Yogyakarta Andi, 2009.

[2] A. Mulyanto, "Sistem Informasi Konsep dan Aplikasi," Yogyakarta: Pustaka Pelajar, 2009.

[3] Abdul Kadir, "Pengenalan Sistem Informasi Edisi Revisi," Edisi Revisi. 2014.

[4] Rohman Heru, "pengertian java," in belajar java, 2019.

[5] Andre, "Tutorial Belajar jQuery: Pengertian jQuery | Duniailkom," duniailkom, 2015. .

[6] Nofriadi, Java Fundamental Dengan Netbeans 8.0.2. 2015.

[7] NetBeans, "NetBeans IDE," Features, 2015.

[8] H. Handayani, "Pengertian Xampp," IJNS - Indones. J. Netw. Secur. - ISSN 2302-5700, 2013.

[9] Arief, "Pengertian Basis Data Informatika," $17 \mathrm{Mei}$ 2013, 2013.

[10] Achmad Yusron Arif, "Pengertian MySQL, Kelebihan Dan Kekurangan,” 2019, 2019.

\section{BIODATA PENULIS}

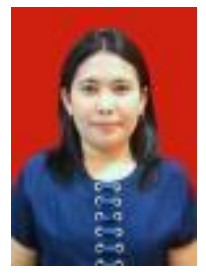

Meri Chrismes Aruan, Dosen Universitas Indraprasta PGRI, Sekaligus menjadi Dosen Pembimbing Materi untuk Penulisan Tugas Akhir atau Skripsi.

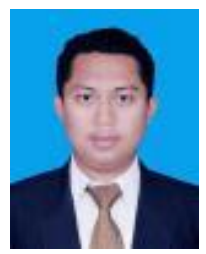

Andri Rahadyan, Dosen Universitas Indraprasta PGRI, Sekaligus menjadi Dosen Pembimbing Teknik untuk Penulisan Tugas Akhir atau Skripsi.

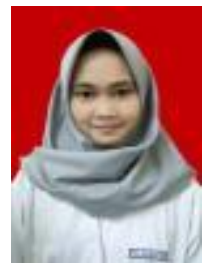

Rina Deviana Alit, Mahasiswi Informatika Fakultas Teknik dan Ilmu Komputer Universitas Indraprasta PGRI, fokus saat ini menjadi Analis Laboratorium Medik pada salah satu Instansi Kesehatandi Kabupaten Bogor. 